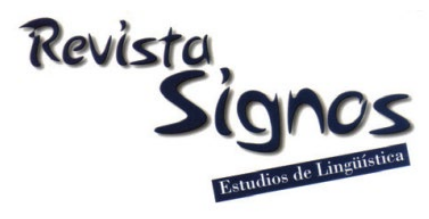

\title{
The influence of language background and second language phonetics training on the perception of lexical stress in a second language
}

\section{La influencia del conocimiento lingüistico y del entrenamiento fonético sobre la percepción del estrés léxico en segunda lengua}

\author{
Todd A. Gibson \\ LOUISIANA STATE UNIVERSITY \\ USA \\ toddandrewgibson@lsu.edu
}

\author{
Carolina Bernales \\ Pontificia Universidad Católica de VALPARAíso \\ CHILE \\ carolina.bernales@pucv.cl
}

Recibido: 19-IX-2018 / Aceptado: 02-IV-2019

DOI: $10.4067 /$ S0718-09342020000100080

\begin{abstract}
Language background and second language (L2) training both have been found to contribute to L2 lexical stress perception. To explore their relative contributions, a lexical stress perception task was administered to a total of 129 university students of different language backgrounds. A group of 62 monolingual English-speaking students in the U.S.A. and 67 English-as-a-foreign-language students in Chile were asked to identify lexical stress in trochees and iambs. Chileans with previous phonetics training performed better than Chileans without the training and performed as well as their U.S. peers. U.S. participants and those Chileans without previous phonetics training performed better with trochees than iambs, but those Chileans with L2 phonetics training performed similarly with both stress patterns. Spanish (L1) ability and English (L2) phonetics training explained variance, but English (L2) ability did not. Results suggest that participants with previous L2 phonetics training developed a general skill to detect lexical stress, while those without such training merely transferred Spanish stress perception to English, which was beneficial because Spanish and English stress patterns are similar for disyllabic words. Pedagogical implications are discussed.
\end{abstract}

Key Words: L2 lexical stress perception, L2 classroom, EFL learning, L2 phonetics training. 


\section{Resumen}

Se ha comprobado que el nivel de conocimiento de una lengua y la instrucción en una segunda lengua (L2) contribuyen a la percepción del acento léxico de una L2. Para explorar estas posibles contribuciones, se administró una tarea de percepción del acento léxico a un total de 129 estudiantes universitarios en dos contextos lingüísticos distintos. Un grupo de 62 estudiantes monolingües de habla inglesa en los EE.UU. y un grupo de 67 estudiantes de inglés como lengua extranjera en Chile participaron en una tarea de identificación del acento léxico en troqueos y yambos. Los chilenos con entrenamiento en fonética se desempeñaron mejor que los chilenos sin entrenamiento, y, a su vez, estos se desempeñaron tan bien como sus pares estadounidenses. Los participantes estadounidenses y los chilenos sin entrenamiento fonético se desempeñaron mejor con troqueos que con yambos, pero los chilenos con entrenamiento fonético en L2 se desempeñaron de manera similar con ambos patrones. El nivel de desempeño en español (L1) y el entrenamiento en fonética del inglés (L2) explicaron esta varianza, pero no así el nivel de desempeño en inglés (L2). Los resultados sugieren que los participantes con entrenamiento en fonética L2 desarrollaron una habilidad general para detectar el acento léxico, mientras que aquellos sin dicho entrenamiento simplemente transfirieron la percepción del acento en español al inglés, lo cual, a su vez, fue beneficioso debido a que los patrones en español e inglés son similares para las palabras bisilábicas. Se discuten implicancias pedagógicas del estudio.

Palabras Clave: Percepción del acento en L2, aprendizaje de idioma extranjero, instrucción fonética en L2.

\section{INTRODUCTION}

Several studies have examined influences on the perception of lexical stress in a second language (L2) (Dupoux, Pallier, Sebastián-Gallés \& Mehler, 1997; Peperkamp, Vendelin \& Dupoux, 2010; Carpenter, 2006, 2015). These influences can be categorized broadly as language background and explicit L2 training. The influence of language background (i.e., the languages known by an individual although degrees of proficiency may differ for each language) has often been attributed to cross-linguistic transfer of learners' first language (L1) language practices to the L2, and vice versa (MacWhinney, 2005). Some studies have shown that the transfer of lexical stress patterns from the L1 impacts listeners' ability to perceive L2 lexical stress (Dupoux et al., 1997). Other studies, however, have suggested that experience with a language in which the placement of lexical stress is highly variable (like Spanish) produces a general sensitivity to lexical stress rather than mere L1 transfer (Peperkamp et al., 2010). Perhaps counterintuitively, however, proficiency in L2 does not appear to have much if any impact on L2 speakers' ability to identify L2 lexical stress. On the other hand, some individuals who are trained to perceive L2 lexical stress have been shown to improve significantly in this ability compared to peers who have not received such training (Carpenter, 2006, 2015). 
Although variables such as language background and explicit L2 training are known to contribute to the perception of L2 lexical stress, the degree of their relative contributions is less clear. The current study sought to identify the relationship between language background and explicit L2 phonetics training with respect to the perception of L2 stress by comparing monolingual English-speaking university students in the United States to Spanish-English bilingual university students in Chile who were studying English as a foreign language. We additionally sought to identify those variables that best predict the successful identification of L2 lexical stress.

\section{Review of literature}

\subsection{L1 influence on L2 lexical stress perception}

Listeners' personal experiences with language influence the way they perceive speech sounds. For example, individuals who have lived in multiple states in the United States are more successful at identifying regional American dialects than individuals who have lived in a single state (Clopper \& Pisoni, 2004). The more similar a listener's dialect is to that of a speaker's own dialect, the more accurately the dialect is identified (Baker, Eddington \& Nay, 2009). Similarly, listeners can easily identify speakers whose first languages differ from their own (Bent, Atagi, Akbik \& Bonifield, 2016).

Bilingual speakers are not only exposed to more than one language, but also to more than one dialect. A significant body of literature has shown that experience with one language influences the perception of another. For instance, Japanese listeners are known to have difficulty identifying the $/ \mathrm{V}-/ 1 /$ contrast in English because $/ 1 /$ is not a member of the Japanese phonemic inventory (Goto, 1971; Best \& Strange, 1992; Aoyama, Flege, Guion, Akahane-Yamada \& Yamada, 2004); Korean speakers typically perceive /I/ as /i/ because /I/ is not present in the Korean phonemic inventory (Baker, Trofimovich, Mack \& Flege, 2002); and Spanish-speaking listeners perceive the English vowels $/ \varepsilon /$ and $/ \mathfrak{x} /$ as the Spanish vowels /e/ and /a/, respectively (Flege, 1991; Flege \& Wayland, 2019). Language background does not only influence the perception of segmental properties but of suprasegmental properties as well. The suprasegmental property of lexical stress has considerable variation across languages, with some relying on it heavily and others not relying on it at all. For example, Spanish speakers are highly dependent on the presence of lexical stress to contrast words (Soto-Faraco, Sebastián-Gallés \& Cutler, 2001) because of its distinctive function (Hualde, 2012, 2014). The Spanish word papa [pápa] means 'potato', but the Spanish word papá [papá] means 'dad'. Shifts in lexical stress also correspond to Spanish morphosyntactic shifts. The Spanish word hablo [áblo] means 'I speak' but the Spanish word babló [abló] means 'he or she spoke'. English uses lexical stress to a lesser extent, with a relatively small set of words changing syntactic category due to alternations in 
stress (e.g., the noun produce [pródus] becomes the verb produce [prodús] with a change in the syllable receiving stress).

Not only do languages differ in the ways in which they use lexical stress to contrast words, but they also differ in their distribution of lexical stress patterns. For example, Cutler and Carter (1987) found that 90\% of English words were either monosyllabic or they were disyllabic with stress on the first syllable (also known as trochees). In English, disyllabic words with the stress on the second syllable (iambs) are rare, with $74 \%$ of disyllabic words being trochees (Delattre, 1965; Cutler, 2015). In French, the distribution of lexical stress is so fixed that French speakers do not have the opportunity to use lexical stress contrastively. All French words have fixed stress on the final syllable of words (Dell \& Vergnaud, 1984). Indeed, not all languages have lexical stress. Korean (Jun, 2005) and Vietnamese (Nguyen \& Ingram, 2005) are tonal languages that use changes in tone instead of stress to contrast words.

The use of lexical stress in the L1 also has been found to influence the perception of lexical stress in the L2. Dupoux et al. (1997) compared French speakers and Spanish speakers on their ability to discriminate between nonwords that differed only in stress (e.g., [mépado], [mepádo], [mepadó]). French speakers who do not use lexical stress contrastively had much more difficulty with this task than Spanish speakers who frequently use lexical stress contrastively. This difficulty was experienced even by French (L1) speakers who were advanced Spanish (L2) learners (Dupoux, SebastianGallés, Navarrete \& Peperkamp, 2008). This was interpreted as a processing problem in which French speakers were not able to encode contrastive stress because of their lack of experience with it. Indeed, the difficulty French-speaking listeners have in identifying lexical stress has been referred to as 'stress deafness' (Dupoux et al., 1997) and has been identified in other languages with fixed stress positions.

The most popular models that explain the impact of L1 on L2 perception focus on segments. Although the specifics differ across models, each proposes that the L1 imposes itself on the ability to discriminate new L2 phonetic contrasts. The perceptual assimilation model (PAM; Best, McRoberts \& Sithole, 1988) proposes that difficulty discriminating L2 contrasts occurs when learners assimilate new L2 phonetic properties into pre-existing L1 categories (e.g., when Japanese speakers assimilate English / $/ /$ into the Japanese / $/$ / category). Similarly, the speech learning model (SLM; Flege, 2007) argues that adult L2 learners easily perceive new L2 contrasts when they are significantly dissimilar to L1 phonetic properties, but become more difficult to perceive as they approach pre-existing L1 phonetic properties. While the SLM focuses on adult L2 learners, the native language magnet model (NLM; Kuhl \& Iverson, 1995) focuses on child language development and asserts that children create phonetic exemplars early in life. These exemplars act like magnets in the phonetic 
space, making it difficult to discriminate new L2 phonetic properties that fall near the exemplars.

The PAM, SLM, and NLM operate by pairing individual phonetic properties to identify the influence of L1 on L2. However, Iverson and Evans (2007) found that experience with an entire phonetic system (e.g., a language's entire vowel system) might be more important for perception than one-to-one comparisons of L1 and L2 phonetic properties. They compared German, Norwegian, Spanish, and French speakers' ability to identify English vowels. German and Norwegian have large, complex vowel systems, with 15 and 18 monophthongal vowels, respectively. Spanish and French, on the other hand, have comparatively small, simple vowel systems with 5 and 11 monophthongal vowels, respectively. Speakers of German and Norwegian performed significantly better than speakers of Spanish and French. The authors interpreted this to mean that speakers with experience with large, complex vowel systems had more practice with cues to vowels than speakers with experience with small, simple vowel systems. This additional practice made them more sensitive to cues that distinguish vowel contrasts.

The results of Iverson and Evans (2007) fit well with the results of Peperkamp et al. (2010), who compared French, Finnish, Hungarian, Polish, and Spanish speakers on their ability to identify lexical stress in nonwords. The authors found a continuum of performance related to the degree of variability in each language's word stress location. Speakers of fixed-stress languages such as Finnish and Hungarian (in which stress is affixed to the first syllable of words) performed poorly compared to speakers of Polish (in which stress is usually penultimate but includes some lexical exceptions). And Polish speakers performed poorly compared to speakers of Spanish (in which stress is usually penultimate but has many lexical exceptions). Similarly, Lukyanchenko, Idsardi, and Jiang (2010) compared the lexical stress perception ability of speakers of Russian, French, and Persian. Russian has many lexical exceptions in stress location, whereas Persian has a limited number of them. Similar to the results by Peperkamp et al. (2010), Russian speakers performed best, French speakers worst, and Persian speakers somewhere in the middle.

Peperkamp et al. (2010) proposed that speakers of languages with high variability in stress systems (i.e., many lexical exceptions in stress location) are better at identifying stress than speakers from languages with low variability (i.e., few or no lexical exceptions in stress location). (Note that this is similar to the proposal by Iverson and Evans (2007) that speakers of languages with high variability in vowel systems are better at identifying vowels in general than speakers from languages with low variability.) This suggests a general enhancement in the ability to perceive lexical stress and not merely the transfer of L1 lexical stress patterns to the L2. Since Spanish has a more variable lexical stress system than English, it might be the case that 
Spanish speakers can identify English word stress as well as or better than English speakers can.

\subsection{Influence of L2 phonetics training on L2 lexical stress perception}

Direct training of L2 lexical stress has been found to exert an influence on segmental perception (Aslin \& Pisoni, 1980). For example, Lively, Logan, and Pisoni (1993) as well as others (Strange \& Dittman, 1984; Werker \& Tees, 1984; Patten \& Edmonds, 2015) have found that Japanese speakers who received intensive phonetic discrimination training significantly improved their ability to distinguish $/ \mathrm{V}$ vs $/ 1 /$. Speakers of Greek, which does not use the short/long or tense/lax distinctions, have been trained successfully to identify vowels that included these distinctions in British English (Lengeris, 2008). Jamieson and Morosan (1986) trained French speakers to successfully identify the / $/$ / vs /ð/ contrast. Wang and Munro (2004) trained Mandarin and Cantonese speakers to perceive three English vowels that do not appear in Mandarin or Cantonese. Portuguese speakers have been trained to perceive English contrasts that do not exist in Portuguese (Bradlow, Pisoni, Akahane-Yamada \& Tohkura, 1997; Reis \& Nobre-Oliveira, 2007). And studies have demonstrated that Spanish speakers learning English can be taught English phonemic contrasts (Sakai, 2016), and English speakers learning Spanish can be taught Spanish phonemic contrasts (Kissling, 2012).

Direct phonetic instruction not only has successfully trained listeners to perceive nonnative segmental contrasts, but some studies have shown that listeners can be trained to perceive nonnative suprasegmental contrasts. For example, Wang, Spench, Jongman, and Sereno (1999) and So (2006) successfully taught English speakers to perceive Mandarin tones, which do not exist lexically in English. Taiwanese speakers, who use tones but not lexical stress contrastively, have been trained to identify English lexical stress (Ou, 2011). French speakers, who, as mentioned above, do not use lexical stress contrastively, have also been trained to identify stress in multisyllabic words (Carpenter, 2006, 2015). Brawerman-Albini, Kluge, Silva, and Albini (2017) successfully taught Brazilian Portuguese speakers to identify preantepenultimate stress, which occurs in English but almost never in Brazilian Portuguese. Romanelli, Menegotto, and Smyth (2015) compared two groups of adult English speakers learning Spanish as an L2 to a group of L1 Spanish speakers. One group of English speakers was trained to identify Spanish lexical stress, and another was trained to identify Spanish segmental contrasts. After three weeks, the group that was explicitly taught Spanish lexical stress could perceive it as well as native Spanish speakers. 


\subsection{The influence of $L 2$ proficiency on L2 lexical stress perception}

Results of studies testing the relationship between proficiency and explicit knowledge of an L2 have been inconsistent. For example, Han and Ellis (1998) found that language proficiency was not related to L2 learners' ability to describe L2 items, structures, and rules (i.e., metalinguistic knowledge) but was strongly related to L2 knowledge about which learners were aware but unable to describe (what the authors referred to as explicit knowledge). However, Alderson, Clapham, and Steel (1997) examined the correlation between scores of explicit French knowledge and French proficiency for first-year university students studying French as an L2. Results showed a moderate relationship between proficiency and knowledge of French among the entire group of 509 participants, but those with the greatest knowledge of French were not the most proficient. The authors proposed that practice with the language, not explicit knowledge of French, was most important for proficiency.

Almost all research on the influence of L2 proficiency on L2 lexical stress has focused on production rather than perception. Although there appears to be a relationship between L2 proficiency and L2 lexical stress production, there is little evidence for such a relationship between proficiency and perception. Many studies have used length of stay or study abroad experience as a proxy for proficiency, and it appears that both of them are related to a reduction of foreign language accent (Lennon, 1990; Towell, Hawkins \& Bazergui, 1996; Muñoz \& Llanes, 2014). Length of stay also has been associated with increased accuracy in English (L2) lexical stress production (Trofimovich \& Baker, 2006). For example, Trofimovich, Gatbonton, and Segalowitz (2007) directly examined the relationship between self-ratings of French (L1) language proficiency and English (L2) stress production. For French (L1) speaking Canadians, English (L2) stress production improved as English proficiency increased.

Few studies, however, have investigated the influence of L2 proficiency on L2 lexical stress perception. Extant results suggest that L2 proficiency does not play a significant role in perceiving L2 lexical stress. Dupoux et al. (2008), mentioned above, found that French speaking learners of Spanish (L2) at beginning, intermediate, and advanced levels of proficiency had respectively similar degrees of difficulty identifying Spanish (L2) lexical stress. Tremblay (2008) placed French-speaking learners of English (L2) into three levels of L2 proficiency based on a cloze test and accentedness ratings. Using a priming paradigm, participants were asked to distinguish English (L2) words based on primary stress. Only those participants with the highest levels of proficiency who were also able to produce the particular targeted stressed syllable were able to successfully perform the perceptual task. 
Testing the same participants as reported in Tremblay $(2008,2009)$ asked French speaking learners of English (L2) to identify lexical stress in English words using an AXB paradigm. Participants listened to pairs of nonsense words that either differed only by lexical stress or differed both by lexical stress and phonemes (but the pairs were nearly identical). There was no statistically significant difference in accuracy across the three levels of proficiency. In fact, these findings suggest that proficiency producing L2 stress and the ability to perceive stress in the same L2 might be dissociated to some extent. For example, Altmann (2006) asked Turkish (L1) speakers to identify English (L2) lexical stress, and although they performed significantly worse than native speakers on this task, they were able to identify English stress as well as native speakers. Therefore, based on the small set of studies performed to date, it does not appear that proficiency in L2 plays any significant role in listeners' ability to perceive L2 lexical stress.

\section{The study}

\subsection{Research Questions}

Based on the above review of the literature, we developed the following questions.

1) What is the relationship between language background and explicit L2 phonetics training to the perception of L2 stress?

2) What variables best predict the successful identification L2 lexical stress?

\subsection{Participants}

Participants included U.S. and Chilean university students. U.S. students were enrolled in a Phonetics course in a Communication Sciences and Disorders department at a four-year university. U.S. students received extra credit for participating. U.S. students were recruited across two consecutive years (50 in the first year and 61 in the second year). We did not include for analysis two U.S. students who reported hearing impairment and two who did not attempt to answer all of the items, which reduced the U.S. sample size to 107. Because U.S. students were to serve as a monolingual English-speaking comparison group, 40 participants were not included for analysis because they reported having some degree of proficiency in an L2. This reduced the U.S. group to 67 participants. Furthermore, we did not include for analysis the results of an additional five U.S. participants because they reported having had a phonetics course previously. This reduced the final group of U.S. participants to 62. Of these, two were men. This distribution of men to women is common in the field of Communication Sciences and Disorders where only 3.7\% of speech-language pathologists in the United States are male (American Speech-Language Hearing Association, 2016; see Table 1 for participant information). 
Sixty-seven Chilean undergraduate students enrolled in a Teaching English as a Foreign Language program volunteered to participate in the study. Eighty-two percent of them were female. Their proficiency in English was Level B2 of the Common European Framework of Reference for Languages (CEFRL; Council of Europe, 2001), which is described as the ability to effectively communicate about a range of topics (e.g., being able to describe a place in detail while guiding visitors; the next level up [C1] is described as being able to deal with hostile questioning). Participants were recruited from two sections of the same class on English syntax. As part of their core coursework, a subset of students had taken a required English phonetics class (they are referred to as students with phonetics training). As part of this course, students were explicitly taught suprasegmental features and contrastive English/Spanish stress patterns. All participants had Spanish as their L1 and English as their L2, and only six of them reported more than two languages (two reported Chinese, two reported French, one reported Hebrew, and another reported both German and French). Selfratings for all additional languages were lower than for English.

Table 1. Means and (in parentheses) standard deviations for demographic variables.

\begin{tabular}{|c|c|c|}
\hline & U.S. & Chilean \\
\hline Age (years) & $20.25(1.08)$ & $20.07(2.19)$ \\
\hline Status & $3.13(.50)$ & $1.28(.45)^{*}$ \\
\hline Spanish self-rating & $\mathrm{N} / \mathrm{A}$ & $8.40(1.34)$ \\
\hline English self-rating & $9.08(.98)$ & $5.62(1.33)^{*}$ \\
\hline L1 self-rating & $9.08(.98)$ & 8.40 (1.34)* \\
\hline$\%$ phonetics training & 0 & $.57^{*}$ \\
\hline$\%$ women & 97 & $82 *$ \\
\hline
\end{tabular}

\subsection{Measures}

\subsubsection{Questionnaires}

Participants filled out a brief questionnaire before the administration of the study (see Appendices A and B). In addition to demographic, health, and academic information, participants self-reported their L1 and L2 abilities as well as their ability to identify lexical stress in each of their languages. Questionnaires for the U.S. and Chilean students differed slightly. U.S. students were asked about their overall language ability instead of being asked about their English language ability specifically (through interpersonal interactions, the first author knew that none of the participants spoke with a nonnative American English dialect; therefore, English ability was not distinguished from language ability for the U.S. group). Chilean students were asked explicitly to rate their Spanish and English language ability separately because it was thought that the concept of overall language ability was unfamiliar, abstract and might cause confusion. 


\subsubsection{Lexical stress stimuli}

Decisions on which words to include in the stimuli were guided by Field (2005). In his study, real words were chosen if they appeared at least once out of one million words in a corpus of spoken English. The list of words for the current study is provided in Appendix C. On average, words in the current study appeared 72.70 times per one million words in the Corpus of Contemporary American English (Davies, 2008). In the current word list, there was no statistically significant difference, $F(1,18)$ $=.61, p=.45$, in the frequency of occurrence for trochees $(M=84.71, S D=69.84)$ and iambs $(M=60.68, S D=60.85)$.

Stimuli were not manipulated with acoustic software. Instead, the speaker (the first author who is a native speaker of English) used a typical, well-articulated speaking voice at a moderate tempo. Because words in lists can have different intonational patterns than words in isolation, each stimulus item was recorded separately and had a naturally falling intonational pattern. Individual WAV files for each word were recorded in a sound booth using a TASCAM DR-05 digital audio recorder. The words were randomized. All participants heard the same randomized list.

\subsubsection{Lexical stress identification}

Participants were asked to report how many syllables were in each word and which syllable received the lexical stress. Participants wrote out the number of syllables they heard (i.e., this was open-ended), and they circled 1, 2, 3, 4, or 5 (forced choice) to identify which syllable received the stress (see Appendix D). If both the number of syllables and the syllable receiving stress were accurately identified, the item was scored as 1 (correct). Otherwise, the item was scored as 0 (incorrect). Reported scores are the average correct.

\subsection{Procedure}

U.S. students participated in this study early in the semester (the fifth of 28 class meetings), before any linguistic perceptual training was begun (only overviews of phonetic transcription as well as the anatomy and physiology of the speech mechanism had been reviewed). The classroom-based study design was influenced by Lee and Lyster (2016) but instead of simulated classrooms, the current study was performed with intact classrooms. Students were seated in a traditional university classroom setting either in the United States or Chile. Upon signing a consent form, students filled out a brief questionnaire. After all students in a classroom had finished filling out the questionnaire, they were provided written instructions (see Appendix D) that were accompanied by a reading of the same instructions. It is important to note here that the instructions presented to participants incorporated a disyllable and a trisyllable so as not to prompt them to expect only disyllabic words. 
For the U.S. group, the first author read the instructions aloud in front of class. To mirror the study as close as possible for the U.S. and Chilean students, the Chilean students had the written instructions before them and listened to a recording of the first author reading the same instructions in the same way that they were presented to the students in the U.S. The level of English of the Chilean participants (B2 CEFRL or above) was sufficient to provide the instructions only in English. Both groups were given the opportunity to ask questions.

In both the United States and Chile, stimuli were presented to students through audio speakers mounted in the front of the classrooms (Chilean students heard the recorded instructions through similar speakers). The volume was sufficient for all students to hear the recordings. Each recording was presented a single time. Five seconds lapsed between the presentation of each stimulus item.

\section{Results}

We sought to determine if performance on the identification of L2 lexical stress differed based on language background and explicit L2 phonetics training (descriptive statistics for each group is provided in Table 2). Toward that end, we performed a one-way ANOVA with percent correct as the dependent variable, and the U.S. participants, Chilean participants without phonetics training, and Chilean participants with phonetics training as the independent variables. The model was statistically significant, $F(3,60)=5.69, p=.002$. A post-hoc Tukey's HSD showed that, at $p<$ .05 , the U.S. group performed better than Chilean participants without phonetics training on overall scores, but there was no statistically significant difference when compared to those Chilean participants with phonetics training. The Chilean participants with phonetics training performed better than those without it.

Table 2. Means and (in parentheses) standard deviations for percent correct identifying lexical stress in disyllabic words.

\begin{tabular}{|l|l|l|l|}
\hline \multicolumn{1}{|c|}{ Group } & \multicolumn{1}{c|}{ Overall } & \multicolumn{1}{c|}{ Trochees } & \multicolumn{1}{c|}{ Iambs } \\
\hline US (n = 62) & $73(17)^{\mathrm{a}, \mathrm{c}}$ & $79(20)^{\mathrm{a}}$ & $68(25)^{\mathrm{a}}$ \\
\hline Chilean without phonetics $(\mathrm{n}=27)$ & $63(17)^{\mathrm{b}, \mathrm{c}, \mathrm{d}}$ & $70(17)^{\mathrm{b}}$ & $56(26)^{\mathrm{b}, \mathrm{e}}$ \\
\hline Chilean with phonetics $(\mathrm{n}=37)$ & $77(14)^{\mathrm{d}}$ & $76(15)$ & $78(23)^{\mathrm{e}}$ \\
\hline
\end{tabular}

Note. Superscripts indicate statistically significant differences with $p<.05$.

As a post-hoc, we sought to determine if the same patterns of differences of overall scores were found when analyzing trochees and iambs separately. The one-way ANOVA with trochees as the dependent variable was statistically nonsignificant, $F(2$, $123)=2.18, p=.11$. However, the one-way ANOVA with iambs as the dependent variable was statistically significant, $F(2,123)=5.88, p=.004$. Post-hoc Tukey's HSD found that Chilean participants with phonetics training performed better than the Chilean participants without phonetics training; furthermore, although Chilean participants with phonetics training performed better than U.S. participants, when identifying lexical stress in iambs, the difference was nonsignificant. 
We performed an additional within-subjects post-hoc analysis to determine if there were statistically significant differences between trochee and iamb performance for all three groups. Paired samples t-tests showed statistically significant differences between performance with trochees and iambs (trochees better than iambs) for the U.S. participants, $t(61)=2.86, p=.006$, and the Chilean participants without phonetics training, $t(26)=2.71, p=.012$. However, there was no statistically significant difference for the Chilean participants with phonetics training, $t(36)=.48, p=.633$.

Our second research question asked which variables were the best predictors for performance identifying L2 lexical stress. To answer this question, English self-ratings, Spanish self-ratings, and the presence or absence of phonetics training were regressed on percent correct for identifying L2 lexical stress. The model was statistically significant, $F(3,60)=5.69, p=.002$, and accounted for $22 \%$ of the variance in overall performance. Two of the three variables uniquely explained variance. Spanish selfratings explained $6.7 \%$, and phonetics training explained an additional $13.8 \%$.

Table 3. Summary of regression analysis for values predicting the identification of L2 lexical stress in disyllabic words.

\begin{tabular}{|c|c|c|c|}
\hline Variable & B & Standard Error & Beta \\
\hline English self-rating & -.014 & .017 & -.109 \\
\hline Spanish self-rating & .036 & .016 & $.282^{*}$ \\
\hline Phonetics training & .135 & .041 & $.388^{*}$ \\
\hline \multicolumn{3}{|c}{ Note. ${ }^{*} p<.05$} \\
\hline
\end{tabular}

Because self-reported L2 proficiency did not have an impact on the identification of L2 lexical stress, we performed a final post-hoc analysis by calculating the correlation between the U.S. speakers' self-ratings of their English abilities and their performance identifying English lexical stress. Pearson's product moment correlation was $r=.08, p=.51$.

\section{Discussion}

Results of the current study suggest that both language background and L2 phonetics training have an impact on listeners' ability to perceive lexical stress in their L2. Although both explain variance in L2 lexical stress perception, L2 phonetics training is the stronger contributor. It appears that, unlike language background, L2 phonetics training results in a general attunement of the listener to L2 lexical stress placement.

\subsection{L1 influence on L2 lexical stress perception}

Several strands of evidence in the current study show that L1 influences lexical stress perception. Although the absolute values for performance on trochees and iambs were higher for the U.S. participants than for the Chilean participants without phonetics training, there was no statistically significant difference between their scores 
when each subset (trochee and iamb) was analyzed individually. When combined for the overall average, the discrepancy in these groups' scores met statistical significance because of the changes in variance between the subset level and the overall level. Nonetheless, Chilean participants without phonetics training performed remarkably similarly (a difference of only 10\%) to their U.S. counterparts who were monolingual English speakers. Additionally, both Chilean and U.S. participants were more successful identifying lexical stress in trochees than in iambs. Furthermore, the results of the multiple regression analysis show that Spanish self-ratings uniquely explain variance in the perception of L2 lexical stress over and above that explained by English self-ratings and L2 phonetics training.

Based on the literature review, we propose that there are at least two possible ways to understand these results. First, participants might simply transfer their L1 stress patterns to the perception of L2 stress patterns. However, another way to understand these results is via the proposal by Peperkamp et al. (2010) in which high variability in lexical stress placement in a language leads to speakers of that language being more attuned to lexical stress placement in general than are speakers of languages with less variability in their lexical stress placement. Since Spanish has greater variability than English, this proposal would predict that Spanish speakers would be more attuned to lexical stress in general. We reason that a general attunement to lexical stress placement should be distributed across trochees and iambs more or less evenly. However, Chilean participants without phonetics training performed better with trochees than iambs. The default pattern for lexical stress in Spanish is for the penultimate syllable to receive the stress. In disyllabic words, that is a trochaic pattern. Therefore, we interpret these results as indicating that the Chilean participants without phonetics training were transferring Spanish patterns of lexical stress to English instead of demonstrating enhanced sensitivity to lexical stress in general. The fact that Spanish and English share similar stress patterns for disyllabic words perhaps enhanced Spanish speakers' performance beyond what might otherwise have been anticipated.

We provide the above as a tentative interpretation; future research should seek to tease apart mere L1 transfer from an overall enhanced sensitivity to lexical stress due to listeners' experience with a high variability L1. However, the current results are quite consistent with the literature that indicates that the L1 indeed has an influence in the perception of L2 lexical stress.

\subsection{Influence of L2 phonetics training on L2 lexical stress perception}

Results of the current study are consistent with the literature that has found a significant contribution of phonetics training to the ability to identify lexical stress. Unlike their Chilean peers who had not received L2 phonetics training, those Chilean 
participants who had phonetics training appeared to have developed a general sensitivity to the perception of lexical stress placement. This assertion is supported by the fact that they not only performed better than their Chilean peers without phonetics training but they performed better than the U.S. monolingual Englishspeaking students. Furthermore, phonetics training explained nearly exactly twice as much variance in L2 lexical stress perception as did Spanish self-ratings.

Perhaps the strongest evidence that these students had developed a generalized ability to identify lexical stress as opposed to merely transferring L1 Spanish patterns to English was the fact that there was no statistically significant difference between their success with trochees and iambs. This means that the skills they developed for identifying lexical stress was applicable across phonetic contexts.

Future studies should further investigate the generalizability of the skills developed from phonetics training and, thus, contribute to the field of instructed second language acquisition by investigating the amount of influence that instruction can have on learners' ability to identify stress. If these skills are generalizable, then we would anticipate that these speakers as compared to peers without phonetics training would perform better at identifying lexical stress in all languages in which lexical stress appears. This could be tested with real words and with nonwords. Additionally, this skill should be manifest in the ability to identify stress in words with more than two syllables as well as the ability to identify secondary stress. Future studies should pursue this line of research.

\subsection{Influence of L2 proficiency on L2 lexical stress perception}

Very few studies have investigated the role of L2 proficiency in the ability to identify lexical stress in the same L2. Results of the current study are consistent with the literature in finding that proficiency in the L2 does not result in improved perception of lexical stress. This seems counterintuitive, especially since many studies have shown that the production of lexical stress improves as length of stay in an L2speaking country increases. To follow up on this result, we calculated the bivariate correlation between the U.S. monolingual English-speaking students' self-ratings of their English (their only language) and their performance identifying English lexical stress. There was no statistically significant correlation. We interpret this to mean that proficiency and perception of lexical stress tap into different underlying processes. Future research should identify sources of this disassociation.

The current results demonstrate how difficult this task is. U.S. participants were monolingual speakers of English, yet on average they failed to identify the location of lexical stress more than $27 \%$ of the time. Future studies should identify obstacles for monolingual English speakers to identify lexical stress in their native language. 


\subsection{Possible cultural influence on self-ratings}

Of interest was the discrepancy between U.S. and Chilean participants' self-ratings of their L1. Monolingual English-speaking U.S. students rated their English abilities higher than bilingual Spanish-English Chilean students rated their Spanish. We suspect this is a cultural artefact. Chilean students are likely more modest in their selfassessments generally than are U.S. students. Future cross-cultural studies should take this into consideration and perhaps use objective measures of language proficiency as a way to control for this cultural difference.

\subsection{Pedagogical implications}

Because phonetics training plays such a significant role in the perception of L2 lexical stress, training in phonetics should occur as early as possible in English language learning coursework. For Spanish learners of English, phonetics instructors might focus their lexical stress instruction on non-trochee words since, in the absence of phonetics training, Spanish speakers appear to transfer their trochee-biased L1 pattern to their perception of English. Additionally, because of its significant impact, phonetics training should be controlled for in future studies that investigate L2 perception (currently, very few research articles make mention of the presence or absence of phonetics training). Finally, we were impressed by the difficulty of this task for monolingual English speakers. Phonetics training is a requirement for becoming a speech-language pathologist in the United States, and some communication disorders include impairments of lexical stress, which speech-language pathologists remediate. This makes it important for these students to be able to identify lexical stress. Therefore, just as phonetics training should occur in the earliest stages of English language learning coursework, speech-language pathology students should receive phonetics training at the earliest stages of speech-language pathology coursework.

\subsection{Limitations}

The current study had several limitations that future studies could improve. Although stimuli were controlled relative to frequency of use and stress location, they were not controlled with respect to other phonetic elements. For example, English but not Spanish incorporates vowel reduction in the unstressed syllable, especially in iambs. Reduced vowels become shorter in duration. In words where this occurs, the stressed syllable becomes relatively long in duration, and long final syllables are generally easier to detect. This might have boosted Spanish-speaking participants' performance on iambs. Future studies should utilize careful phonetic controls over stimuli, perhaps through the use of nonwords. We measured language proficiency via self-ratings and did not include objective measures of language ability. Since there was a difference between the L1 self-ratings of U.S. and Chilean participants, this measurement may have impacted results in a way that objective measures would not. This limitation could be remediated by including objective measures of language 
ability in future research. The U.S. group only included two males, while there was a greater distribution of gender in the Chilean group. To overcome this limitation, future studies should attempt to match for sex since some research has indicated that there are sex differences in language ability. Also, the current study was performed in a classroom setting, which may have introduced some level of statistical noise that could be reduced in a laboratory setting. Finally, since Chilean students start learning English as a compulsory subject in elementary school, we did not ask participants the age at which they first began learning English. Some studies have shown that early exposure to the L2 is associated with enhanced perception of L2 stress (Guion, Harada \& Clark, 2004; Guion, 2005; Wayland, Landfair, Li \& Guion, 2006). Future studies on this topic should control for age of acquisition of the L2.

\section{CONCLUSIONS}

Language background and explicit L2 phonetics training influence the ability to perceive L2 lexical stress. However, explicit L2 phonetics training plays an outsized role when compared to language background. Without explicit L2 phonetics training, Spanish speakers merely transfer their L1 lexical stress patterns to the perception of English (L2) lexical stress. The level of proficiency in a language appears to have no bearing on the perception of lexical stress, even for monolingual English speakers.

\section{REFERENCES}

Alderson, J. C., Clapham, C. \& Steel, D. (1997). Metalinguistic knowledge, language aptitude and language proficiency. Language Teaching Research, 1(2), 93-121.

Altmann, H. (2006). The perception and production of second language stress: A cross-linguistic experimental study. Unpublished doctoral dissertation, University of Delaware, Newark, U.S.A.

American Speech-Language Hearing Association (2016). Highlights and trends: Member and affiliate counts, year-end 2016 [on line]. Retrieved from: https://www.asha.org/uploadedFiles/2016-Member-Counts.pdf

Aoyama, K., Flege, J. E., Guion, S. G., Akahane-Yamada, R. \& Yamada, T. (2004). Perceived phonetic dissimilarity and L2 speech learning: The case of Japanese/r/and English/1/and/r. Journal of Phonetics, 32(2), 233-250.

Aslin, R. N. \& Pisoni, D. B. (1980). Effects of early linguistic experience on speech discrimination by infants: A critique of. Child Development, 51(1), 107-112.

Baker, W., Eddington, D. \& Nay, L. (2009). Dialect identification: The effects of region of origin and amount of experience. American Speech, 84(1), 48-71. 
Baker, W., Trofimovich, P., Mack, M. \& Flege, J. E. (2002). The effect of perceived phonetic similarity on non-native sound learning by children and adults. In A. Do, L. Dominguez, A. Johansen (Eds.), BUCLD 26: Proceedings of the 26th annual Boston University Conference on Language Development (pp. 36-47). Somerville, MA: Cascadilla Press.

Bent, T., Atagi, E., Akbik, A. \& Bonifield, E. (2016). Classification of regional dialects, international dialects, and nonnative accents. Journal of Phonetics, 58, 104-117.

Best, C. T., McRoberts, G. W. \& Sithole, N. M. (1988). Examination of perceptual reorganization for nonnative speech contrasts: Zulu click discrimination by English-speaking adults and infants. Journal of Experimental Psychology: Human Perception and Performance, 14(3), 345-360.

Best, C. T. \& Strange, W. (1992). Effects of phonological and phonetic factors on cross-language perception of approximants. Journal of Phonetics, 20(3), 305-330.

Bradlow, A. R., Pisoni, D. B., Akahane-Yamada, R. \& Tohkura, Y. (1997). Training Japanese listeners to identify English /r/ and /1/: IV. Some effects of perceptual learning on speech production. The Journal of the Acoustical Society of America, 101(4), 2299-2310.

Brawerman-Albini, A., Kluge, D. C., Silva, A. H. \& Albini, L. C. P. (2017). Perceptual training effects on the acquisition of English stress by Brazilian learners. International Journal of English Linguistics, 7(6), 1-15.

Carpenter, A. C. (2006). Acquisition of a natural versus an unnatural stress system. Unpublished doctoral dissertation, University of Massachusetts Amherst, ProQuest Dissertations Publishing (Order No 3215919).

Carpenter, A. C. (2015). Phonetic training significantly mitigates the stress 'deafness' of French speakers. International Journal of Linguistics, 7(3), 94-108.

Clopper, C. G. \& Pisoni, D. B. (2004). Homebodies and army brats: Some effects of early linguistic experience and residential history on dialect categorization. Language V ariation and Change, 16(1), 31-48.

Council of Europe. (2001). Common European framework of reference for languages: Learning, teaching, assessment. Cambridge, UK: Cambridge University Press.

Cutler, A., (2015). Lexical stress in English pronunciation. In M. Reed \& J. Levis (Eds.), The handbook of English pronunciation (pp. 106-124). John Wiley \& Sons.

Cutler, A. \& Carter, D. M. (1987). The predominance of strong initial syllables in the English vocabulary. Computer Speech \& Language, 2(3-4), 133-142. 
Davies, M. (2008). The corpus of contemporary American English (COCA): 520 million words, 1990-present [on line]. Retrieved from: http://corpus.byu.edu/coca/.

Delattre, P. (1965). Comparing the phonetic features of English, French, German and Spanish: An interim report. Groos, Heidelberg: Julius Groos Verlag.

Dell, F. \& Vergnaud, J. R. (1984). Les développements récents en phonologie: Quelques idées centrales. In F. Dell, D. Hirst \& J. R. Vergnaud (Eds.), Forme sonore du langage (pp. 1-42). Paris: Hermann.

Dupoux, E., Pallier, C., Sebastian-Gallés, N. \& Mehler, J. (1997). A destressing 'deafness' in French? Journal of Memory and Language, 36(3), 406-421.

Dupoux, E., Sebastián-Gallés, N., Navarrete, E. \& Peperkamp, S. (2008). Persistent stress 'deafness': The case of French learners of Spanish. Cognition, 106(2), 682-706.

Field, J. (2005). Intelligibility and the listener: The role of lexical stress. TESOL Quarterly, 39(3), 399-423.

Flege, J. E. (1991). The interlingual identification of Spanish and English vowels: Orthographic evidence. The Quarterly Journal of Experimental Psychology, 43(3), 701-731.

Flege, J. E. (2007). Language contact in bilingualism: Phonetic system interactions. In J. Cole \& J. Hualde (Eds.), Laboratory Phonology 9 (pp. 353-380). Berlin: Mouton de Gruyter.

Flege, J. E. \& Wayland, R. (2019). The role of input in native Spanish Late learners' production and perception of English phonetic segments. Journal of Second Language Studies, 2(1), 1-44.

Goto, H. (1971). Auditory perception by normal Japanese adults of the sounds L and R. Neuropsychologia, 9, 317-323.

Guion, S. G. (2005). Knowledge of English word stress patterns in early and late Korean-English bilinguals. Studies in Second Language Acquisition, 27(4), 503-533.

Guion, S. G., Harada, T. \& Clark, J. J. (2004). Early and late Spanish-English bilinguals' acquisition of English word stress patterns. Bilingualism: Language and Cognition, 7(3), 207-226.

Han, Y. \& Ellis, R. (1998). Implicit knowledge, explicit knowledge and general language proficiency. Language teaching research, 2(1), 1-23. 
Hualde, J. I. (2012). Stress and rhythm. In J. I. Hualde, A. Olarrea \& E. O’Rourke (Eds.), The handbook of Hispanic linguistics (pp. 152-171). Malden, MA: WileyBlackwell.

Hualde, J. I. (2014). Los sonidos del español. Cambridge University Press.

Iverson, P. \& Evans, B. G. (2007). Learning English vowels with different firstlanguage vowel systems: Perception of formant targets, formant movement, and duration. The Journal of the Acoustical Society of America, 122(5), 2842-2854.

Jamieson, D. G. \& Morosan, D. E. (1986). Training non-native speech contrasts in adults: Acquisition of the English /ð/-/ $\theta /$ contrast by francophones. Perception, \& Psychophysics, 40(4), 205-215.

Jun, S. A. (2005). Korean intonational phonology and prosodic transcription. In S. A. Jun (Ed.), Prosodic typology: The phonology of intonation and phrasing (pp. 201-229). New York: Oxford University Press.

Kissling, E. M. (2012). The effect of phonetics instruction on adult learners' perception and production of L2 sounds. Unpublished doctoral dissertation, Georgetown University, ProQuest Dissertations Publishing (Order No 3502930).

Kuhl, P. K. \& Iverson, P. (1995). Linguistic experience and the 'Perceptual Magnet Effect.' In W. Strange (Ed.), Speech Perception and Linguistic Experience: Issues in Cross-language Research (pp. 121-154). Baltimore, MD: York Press.

Lee, A. H., \& Lyster, R. (2016). The effects of corrective feedback on instructed L2 speech perception. Studies in Second Language Acquisition, 38(1), 1-30.

Lengeris, A. (2008). The effectiveness of auditory phonetic training on Greek native speakers' perception and production of Southern British English vowels. In Proceedings of the 2nd ISCA Workshop on Experimental Linguistics (pp. 133-136) Athens, Greece.

Lennon, P. (1990). Investigating fluency in EFL: A quantitative approach. Language learning, 40(3), 387-417.

Lively, S. E., Logan, J. S. \& Pisoni, D. B. (1993). Training Japanese listeners to identify English /r/ and /1/. II: The role of phonetic environment and talker variability in learning new perceptual categories. The Journal of the Acoustical Society of America, 94, 1242-1255. 
Lukyanchenko, A., Idsardi, W. J. \& Jiang, N. (2010). Opening your ears: The role of L1 in processing of nonnative prosodic contrasts. In G. Granena, J. Koeth, S. Lee-Ellis, A. Lukyanchenko, G. Prieto Botana \& E. Rhoades (Eds.), Selected Proceedings of the 2010 Second Language Research Forum: Reconsidering SLA Research, Dimensions, and Directions (pp. 50-62). Somerville, MA: Cascadilla Press.

MacWhinney, B. (2005). A unified model of language acquisition. In J. F. Kroll \& A. M. B. de Groot (Eds.), Handbook of bilingualism: Psycholinguistic approaches (pp. 49-67). New York: Oxford University Press.

Muñoz, C. \& Llanes, Á. (2014). Study abroad and changes in degree of foreign accent in children and adults. The Modern Language Journal, 98(1), 432-449.

Nguyen, T. A. T. \& Ingram, J. (2005). Vietnamese acquisition of English word stress. TESOL Quarterly, 39, 309-319.

Ou, S. C. (2011). Training Taiwanese EFL learners to perceive English lexical stress contrast: A pilot study. In Proceedings of the 17th International Congress of Phonetic Sciences (pp. 150-153). Hong Kong, China.

Patten, I. \& Edmonds, L. A. (2015). Effect of training Japanese L1 speakers in the production of American English/r/using spectrographic visual feedback. Computer Assisted Language Learning, 28(3), 241-259.

Peperkamp, S., Vendelin, I. \& Dupoux, E. (2010). Perception of predictable stress: A cross-linguistic investigation. Journal of Phonetics, 38(3), 422-430.

Reis, M. \& Nobre-Oliveira, D. (2007). Effects of perceptual training on the identification and production of English voiceless plosives aspiration by Brazilian EFL learners. In A. S. Rauber, M. A. Watkins \& B. O. Baptista (Eds.), New Sounds: Proceedings of the Fifth International Symposium on the Acquisition of Second Language Speech (pp. 398-407). Florianópolis: Universidade Federal de Santa Catarina.

Romanelli, S., Menegotto, A. C. \& Smyth, R. (2015). Stress perception: Effects of training and a study abroad program for L1 English late learners of Spanish. Journal of Second Language Pronunciation, 1(2), 181-210.

Sakai, M. (2016). (Dis)connecting perception and production: Training native speakers of Spanish on the English /i/-/I/ distinction. Unpublished doctoral dissertation, Georgetown University, ProQuest Dissertations Publishing (Order $\mathrm{N}^{\circ}$ 10250896). 
So, C. K. (2006). Effects of L1 prosodic background and AV training on learning Mandarin tones by speakers of Cantonese, Japanese, and English. Unpublished doctoral dissertation, Simon Fraser University, Burnaby, British Columbia, USA.

Soto-Faraco, S., Sebastián-Gallés, N. \& Cutler, A. (2001). Segmental and suprasegmental mismatch in lexical access. Journal of Memory and Language, 45, 412-432.

Strange, W. \& Dittmann, S. (1984). Effects of discrimination training on the perception of/rl/by Japanese adults learning English. Perception \& Psychophysics, 36(2), 131-145.

Towell, R., Hawkins, R. \& Bazergui, N. (1996). The development of fluency in advanced learners of French. Applied Linguistics, 17(1), 84-119.

Tremblay, A. (2008). Is second language lexical access prosodically constrained? Processing of word stress by French Canadian second language learners of English. Applied Psycholinguistics, 29(4), 553-584.

Tremblay, A. (2009). Phonetic variability and the variable perception of L2 word stress by French Canadian listeners. International Journal of Bilingualism, 13(1), 35-62.

Trofimovich, P. \& Baker, W. (2006). Learning second language suprasegmentals: Effect of L2 experience on prosody and fluency characteristics of L2 speech. Studies in Second Language Acquisition, 28(1), 1-30.

Trofimovich, P., Gatbonton, E. \& Segalowitz, N. (2007). A dynamic look at L2 phonological learning: Seeking processing explanations for implicational phenomena. Studies in Second Language Acquisition, 29(3), 407-448.

Wang, X. \& Munro, M. J. (2004). Computer-based training for learning English vowel contrasts. System, 32(4), 539-552.

Wang, Y., Spence, M. M., Jongman, A. \& Sereno, J. A. (1999). Training American listeners to perceive Mandarin tones. The Journal of the Acoustical Society of America, 106(6), 3649-3658.

Wayland, R., Landfair, D., Li, B. \& Guion, S. G. (2006). Native Thai speakers' acquisition of English word stress patterns. Journal of Psycholinguistic Research, 35(3), 285-304.

Werker, J. F. \& Tees, R. C. (1984). Cross-language speech perception: Evidence for perceptual reorganization during the first year of life. Infant behavior and development, 7(1), 49-63. 


\section{APPENDIX}

\section{Appendix A}

\section{Questionnaire administered to U.S. participants}

1) What is your age?

2) What is your sex? Female Male

3) What is your college major?

2) What is your overall GPA?

3) Do you have any speech, language, cognition, or hearing problems? Yes No If Yes, please describe:

4) Which of the following best represents your current university status (please circle)

Freshman Sophomore Junior Senior Graduate Student

5) Have you taken a class devoted to phonetics before? Yes No

6) Please rate your overall language ability (independent of any particular language) on a scale from 0 to 10

7) Please rate your ability to identify stress in words on a scale from 0 to 10

8) Do you speak a language other than English? Yes No

9) If you speak a language other than English, what is/are the language/s

10) Please rate your proficiency in that/those language/s on a scale from 1 to 10

\section{Appendix B}

\section{Questionnaire administered to Chilean participants}

1) What is your age?

2 ) What is your gender?

3) What is your overall coursework average?

4) Do you have any speech, language, cognition, or hearing problems? Yes No If Yes, please describe:

5) Which of the following best represents your current university status (please circle)

\section{Freshman Sophomore Junior Senior}

6) Have you taken a class devoted to phonetics before? Yes No

7) Please rate your overall language ability in Spanish on a scale from 0 to 10

8) Please rate your overall language ability in English on a scale from 0 to 10 
9) Please rate your ability to identify stress in Spanish words on a scale from 0 to

10) Please rate your ability to identify stress in English words on a scale from 0 to

11) Do you speak a language other than English and Spanish? Yes No

12) If you speak a language other than English/Spanish, what is/are the language/s?

13) Please rate your proficiency in that language on a scale from 0 to 10

\section{Appendix C}

\section{Word list}

Notice

Provide

Supply

Suppose

Locate

Open

Explain

Measure

Contain

Answer

Listen

Express

Accuse

Study

Finish

Carry

Settle

Appear

Become

Complete

\section{Appendix D}

\section{Instructions for the lexical stress identification form}

A syllable is a unit of speech sound that includes a vowel and may include surrounding consonants. For example, chair has 1 syllable, sofa has 2 syllables, and recliner has 3 syllables. In what follows, you will hear a series of real and fake words. For each item, write down how many syllables you hear. For example, if you heard the word sofa, 
you would write the number 2 in the space provided. Each of the items will have a syllable that receives primary stress (the most emphasis). Circle the number that corresponds with the syllable that receives primary stress. For example, sofa has 2 syllables, and the first syllable receives primary stress. In this case, you would circle the number 1 to indicate that the first syllable receives primary stress. Recliner has 3 syllables, and the second syllable receives primary stress. You will hear each word once. You will have 5 seconds to identify the primary stress for each item. If you're not sure, guess. Do not leave any questions unanswered.

Sofa

\begin{tabular}{|l|l|l|l|l|l|l|}
\hline Item & \# of syllables & \multicolumn{5}{l|}{ Syllable receiving primary stress } \\
\hline $\mathrm{A}$ & 2 & 1 & 2 & 3 & 4 & 5 \\
\hline
\end{tabular}

Recliner

\begin{tabular}{|c|c|c|c|c|c|}
\hline Item & \# of syllables & \multicolumn{4}{|c|}{ Syllable receiving primary stress } \\
\hline A & & 1 & 3 & 4 & 5 \\
\hline
\end{tabular}

INSTRUCTIONS: Listen to the words and identify the number of syllables you hear. Indicate where each word is stressed.

\begin{tabular}{|l|l|l|l|l|l|l|}
\hline Item & \# of syllables & \multicolumn{5}{c|}{ Syllable receiving primary stress } \\
\hline A & & 1 & 2 & 3 & 4 & 5 \\
\hline B & & 1 & 2 & 3 & 4 & 5 \\
\hline C & & 1 & 2 & 3 & 4 & 5 \\
\hline D & & 1 & 2 & 3 & 4 & 5 \\
\hline E & & 1 & 2 & 3 & 4 & 5 \\
\hline F & & 1 & 2 & 3 & 4 & 5 \\
\hline G & & 1 & 2 & 3 & 4 & 5 \\
\hline H & & 1 & 2 & 3 & 4 & 5 \\
\hline I & & 1 & 2 & 3 & 4 & 5 \\
\hline J & & 1 & 2 & 3 & 4 & 5 \\
\hline K & & 1 & 2 & 3 & 4 & 5 \\
\hline L & & 1 & 2 & 3 & 4 & 5 \\
\hline M & & 1 & 2 & 3 & 4 & 5 \\
\hline N & & 1 & 2 & 3 & 4 & 5 \\
\hline O & & 1 & 2 & 3 & 4 & 5 \\
\hline P & & 1 & 2 & 3 & 4 & 5 \\
\hline Q & & 1 & 2 & 3 & 4 & 5 \\
\hline R & & 1 & 2 & 3 & 4 & 5 \\
\hline S & & 1 & 2 & 3 & 4 & 5 \\
\hline T & & 1 & 2 & 3 & 4 & 5 \\
\hline
\end{tabular}

